Article

\title{
Numerical Study of Heat Transfer Enhancement for Laminar Nanofluids Flow
}

\author{
Ramon Ramirez-Tijerina ${ }^{1}$ (D), Carlos I. Rivera-Solorio ${ }^{1, *}$, Jogender $\operatorname{Singh}^{1}$ and K. D. P. Nigam ${ }^{1,2}$ \\ 1 Tecnologico de Monterrey, School of Engineering and Science, Ave. Eugenio Garza Sada 2501, \\ Monterrey CP 64849, N.L., Mexico; A00780793@itesm.mx (R.R.-T.); jogender8295@gmail.com (J.S.); \\ nigamkdp@gmail.com (K.D.P.N.) \\ 2 Indian Institute of Technology Delhi, Department of Chemical Engineering, New Delhi 110016, India \\ * Correspondence: rivera.carlos@tec.mx; Tel.: +52-81-8358-2000 (ext. 5263)
}

Received: 30 October 2018; Accepted: 29 November 2018; Published: 18 December 2018

check for updates

\begin{abstract}
The laminar forced convection has been investigated for the flow of nanofluids in conventional straight tube $\left(L=5.34 \mathrm{~m}, \mathrm{~d}_{\mathrm{t}}=10 \mathrm{~mm}\right)$ and straight microtube $\left(\mathrm{L}=0.3 \mathrm{~m}, \mathrm{~d}_{\mathrm{t}}=0.5 \mathrm{~mm}\right)$ under the constant temperature and constant heat flux conditions, separately. A wide range of the process parameters has been studied by varying three different type of base fluids including water, ethylene glycol and turbine oil with five different type of nanoparticles viz. $\mathrm{Al}_{2} \mathrm{O}_{3}, \mathrm{TiO}_{2}$, $\mathrm{CuO}, \mathrm{SiO}_{2}$ and $\mathrm{ZnO}$. Six different combinations of the geometries, base fluids and nanoparticle concentrations are considered in the present study. In addition to the single-phase model (SPH), the single-phase dispersion model (SPD) has been also used for effectiveness of the computed results. The results showed that Nusselt number $(\mathrm{Nu})$ increases with increase in Reynolds number (Re). Further, the Nu considerably enhanced (up to $16 \%$ at volume fraction $\phi_{b}=4 \%, \operatorname{Re}=950$ ) with increase in nanoparticle concentrations. Heat transfer correlations are developed for the flow of nanofluids in conventional straight tube and straight microtube over a wide range of process conditions $\left(25<\operatorname{Re}<1500,0<\phi_{b}<10,6<\operatorname{Pr}<500\right)$ to enable a large number of engineering applications.
\end{abstract}

Keywords: nanofluids; laminar force convection; heat exchangers; heat transfer enhancement; microtube

\section{Introduction}

Heat transfer is an essential component in nearly all industrial processes [1-5]. Consequences of improper heat transfer include nonreproducible processing conditions and lower product quality. Straight tube heat exchangers are the most common type of heat exchanger used in industrial processes due to ease of manufacturing and lower cost [1]. There are several experimental works available in the literature that study forced convective heat transfer in nanofluids as it continues to be a subject of growing importance in many applications [2-19]. A straight tube heat exchanger with laminar flow condition has a lower heat transfer coefficient (HTC) as compared to turbulent flow conditions. Conventional heat transfer fluids such as water, ethylene glycol, and engine oil have relatively low thermal conductivity values, which thus limit the heat transfer rates. The heat transfer performance can be enhanced either by geometry perturbation or by the improvement of the fluid properties. The nanofluids are considered the next-generation heat transfer fluids because of the new possibilities (i.e., more heat transfer surface between particles and fluids, reduced pumping power to achieve equivalent heat transfer intensification, etc.) compared to pure liquids. The term nanofluids refers to a two-phase mixture composed of a continuous phase, usually a saturated liquid, and a dispersed phase constituted of extremely fine metallic particles of a size below $100 \mathrm{~nm}$ called nanoparticles.

It has been shown that the thermal properties of a nanofluid appear to be higher than those of the base fluid. Hence, nanofluids appear to be an interesting alternative for advanced thermal applications 
for microscale and nanoscale heat transfer. Alumina oxide nanoparticles $\left(\mathrm{Al}_{2} \mathrm{O}_{3}\right)$ has been widely used for both experimental and numerical work [20-30]. Wen and Ding [20] developed a series of experiments using $\mathrm{Al}_{2} \mathrm{O}_{3}$-water nanofluids in a circular tube. They observed that the local HTC was enhanced by $47 \%$ using $\mathrm{Al}_{2} \mathrm{O}_{3}$ nanoparticles for $\phi_{b}=1.6 \%$, in the laminar flow regime. Maïga et al. [21] investigated $\mathrm{Al}_{2} \mathrm{O}_{3}$-water and $\mathrm{Al}_{2} \mathrm{O}_{3}$-ethylene glycol under constant heat flux boundary condition. The reported results show a $63 \%$ enhancement in HTC for $\phi_{b}=7.5 \%$. Heris et al. [22] studied the laminar convective heat transfer of $\mathrm{CuO}$-water and $\mathrm{Al}_{2} \mathrm{O}_{3}$-water nanofluids flow in the straight tube and reported that the HTC increases with an increase in particle loading and a decrease in the particle size. The HTC was augmented by $40 \%$ for $\mathrm{Al}_{2} \mathrm{O}_{3}$-water at $\phi_{b}=2.5 \%$. Anoop et al. [23] conducted experiments using an aqueous solution of $\mathrm{Al}_{2} \mathrm{O}_{3}$-water in the developing region of a pipe flow to calculate the HTC considering the influence of particle size. The experimental results showed a $25 \%$ HTC enhancement for a $45-\mathrm{nm}$ particle size and $11 \%$ for a $150-\mathrm{nm}$ particle size. It was concluded that heat transfer enhancement was not only due to the intensification in thermal conductivity but also because of the effects of particle migration and thermal dispersion. Hwang et al. [24] measured the pressure drop and convective heat transfer of water-based $\mathrm{Al}_{2} \mathrm{O}_{3}$ nanofluids flowing through a uniformly heated circular tube in the fully developed laminar flow regime. The experimental results showed that the HTC increases up to $8 \%$, at $\phi_{b}=0.3 \%$ as compared to water.

Davarnejad et al. [25] performed simulations to investigate the heat transfer characteristics of water-based $\mathrm{Al}_{2} \mathrm{O}_{3}$ nanofluid with $\phi_{b}=0.5 \%-2.5 \%$, in a circular tube under constant heat flux and laminar flow conditions. It was reported that HTC enhanced marginally by $6 \%$ at $\phi_{b}=2.5 \%$, as compared to the water. Kim et al. [26] investigated the effect of nanofluids on convective heat transfer through a circular straight tube with constant heat flux condition under both the laminar and turbulent flow regimes. For $\mathrm{Al}_{2} \mathrm{O}_{3}$ nanofluids with $\phi_{b}=3 \%$, the thermal conductivity and HTC increases by $8 \%$ and $20 \%$, respectively. The enhancement of the convective HTC at the entrance region was due to the Brownian motion of the nanoparticles. Rea et al. [27] investigated the laminar convective heat transfer and viscous pressure loss for $\mathrm{Al}_{2} \mathrm{O}_{3}$-water and $\mathrm{ZrO}_{2}$-water nanofluids flow in a vertical heated tube. The HTC's in the entrance and fully developed regions were found to be enhanced by $17 \%$ and $27 \%$, respectively, for water-based $\mathrm{Al}_{2} \mathrm{O}_{3}$ nanofluid at $\phi_{b}=6 \%$, as compared to the water. Purohit et al. [28] studied the laminar forced convective heat transfer in a circular tube for three different nanofluids $\left(\mathrm{Al}_{2} \mathrm{O}_{3}\right.$-water, $\mathrm{ZrO}_{2}$-water and $\mathrm{TiO}_{2}$-water). They reported that for the same $\mathrm{Re}$ comparison criteria, the HTC for nanofluids is found to be significantly higher (18\%) as compared to the base fluid. Haghighi et al. [29] investigated the heat transfer characteristics of a straight microtube for three different nanofluids $\left(\mathrm{Al}_{2} \mathrm{O}_{3}\right.$-water, $\mathrm{ZrO}_{2}$-water and $\mathrm{TiO}_{2}$-water) under laminar condition $(\operatorname{Re}=200-2200)$. For the nanofluids considered, the HTC was reported enhanced by $23 \%$ as compared to water. Salman et al. [30] utilized a numerical method to investigate the convective heat transfer of nanofluids in microtube under constant heat flux with different types of nanoparticles $\left(\mathrm{Al}_{2} \mathrm{O}_{3}, \mathrm{CuO}\right.$, $\mathrm{SiO}_{2}$ and $\mathrm{ZnO}$ ) with different volume fractions ranged from $1 \%$ to $4 \%$ using ethylene glycol and water as a base fluid. The maximum heat transfer enhancement was $22 \%$.

Table 1 shows a summary of the different nanofluids and their process parameters (Re, Pr and $\phi_{b}$ ) for convection heat transfer under laminar flow condition. The parameters were selected based on the potential of the nanofluids for their practical applications as studied by previous authors and presented in Table 1. The highest Prandtl number and volume fraction of nanoparticles were 753 and $\phi_{b}=10 \%$, respectively.

The extensive studies, both experimental and theoretical have been conducted to calculate the convective HTC of the nanofluids flow in straight tube. It is conclusive from the literature review that the HTC not only enhanced by the thermal conductivity but also due to the disturbances of thermal boundary layer caused by the Brownian motion of the nanoparticles. It may also be noted that there are only few studies with a wider range of nanoparticles and particle concentrations. This is mainly because the experimental analysis can be complicated for the wider range of the design parameters. 
A considerable amount of research has been done on nanofluids over the past decade, the conclusions on their behavior, characteristics, and performances remain somewhat controversial. There is still lack of consistency in experimental values found in the literature [18,19] and challenges that need to be addressed and overcome before this new field of study can be fully established. It is imperative to conduct more investigations to properly quantify the effects of nanoparticles in heat transfer enhancement.

Table 1. The different nanofluids and their process parameters.

\begin{tabular}{ccccc}
\hline Author & Nanofluids & Re Range & Pr Range & $\phi_{b}$ \\
\hline Wen and Ding [20] & $\mathrm{Al}_{2} \mathrm{O}_{3}$-water & $500-2100$ & $6-12$ & $0.6-1.6$ \\
Maïga et al. [21] & $\mathrm{Al}_{2} \mathrm{O}_{3}$-water, $\mathrm{Al}_{2} \mathrm{O}_{3}$-EG & $250-1000$ & $6-753$ & $0-10.0$ \\
Heris et al. [22] & $\mathrm{CuO}$-water, $\mathrm{Al}_{2} \mathrm{O}_{3}$-water & $650-2050$ & $6-12$ & $0.2-3.0$ \\
Anoop et al. [23] & $\mathrm{CuO}$-Turbine Oil, $\mathrm{TiO}_{2}$-Turbine Oil, $\mathrm{Al}_{2} \mathrm{O}_{3}$-Turbine Oil & $650-2050$ & $350-500$ & $0-1$ \\
Hwang et al. [24] & $\mathrm{Al}_{2} \mathrm{O}_{3}$-water & $500-2000$ & $6-12$ & $1.0-6.0$ \\
Davarnejad et al. [25] & $\mathrm{Al}_{2} \mathrm{O}_{3}$-water & $500-800$ & $6-12$ & $0.01-0.3$ \\
Kim et al. [26] & $\mathrm{Al}_{2} \mathrm{O}_{3}$-water & $420-990$ & $6-12$ & $0.5-2.5$ \\
Rea et al. [27] & $\mathrm{Al}_{2} \mathrm{O}_{3}$-water & $800-2400$ & $6-12$ & $0-3$ \\
Purohit et al. [28] & $\mathrm{Al}_{2} \mathrm{O}_{3}$-water, $\mathrm{ZrO}_{2}$-water & $10-2000$ & $6-12$ & $0-6.0$ \\
Haghighi et al. [29] & $\mathrm{Al}_{2} \mathrm{O}_{3}$-water, $\mathrm{ZrO}$-water, $\mathrm{TiO}_{2}$-water & $1150-1900$ & $6-12$ & $0.5-2$ \\
Salman et al. [30] & $\mathrm{Al}_{2} \mathrm{O}_{3}$-water, $\mathrm{ZrO}$-water, $\mathrm{TiO}$-water & $10-2300$ & $6-12$ & 2.3 \\
\hline
\end{tabular}

Therefore, in this study, the single-phase model was used for a wide range of nanofluid properties including three different base fluids with Prandtl numbers ranging from 6-500 and five different nanoparticles viz. $\mathrm{Al}_{2} \mathrm{O}_{3}, \mathrm{TiO}_{2}, \mathrm{CuO}, \mathrm{SiO}_{2}$, and $\mathrm{ZnO}$. The wide range of fluid properties enables the evaluation of the performance of convective heat transfer in a larger number of engineering applications that can benefit from a better understanding of the thermal enhancement of nanofluids. Furthermore, it is important to understand that the usefulness of nanofluids for heat transfer applications depends not only on the thermal conductivity but also on other transport properties, such as viscosity, and on thermodynamic properties, such as specific heats. The wide range of nanofluid properties will allow us to produce relevant $\mathrm{Nu}$ correlations, and more importantly, enable control by proper selection of particles and base fluids.

\section{Mathematical Formulation}

The mathematical modeling of the nanofluids is done using single phase approach. Single-phase models (SPH) including dispersion model (SPD) assumes that the base fluid and the nanoparticles have the same temperature and velocity field. Therefore, the single phase nanofluid flow was assumed as a steady incompressible flow and the continuity, momentum and energy equations are solved using the effective properties of the nanofluids. Similar assumptions were made in the literature for the single phase nanofluid flow [31,32].

\subsection{Governing Equations}

The present study was conducted for both the constant heat flux $\left(q_{w}^{\prime \prime}=10,000 \mathrm{~W} / \mathrm{m}^{2}\right)$ and constant wall temperature $\left(\mathrm{T}_{\mathrm{W}}=313.15 \mathrm{~K}\right)$ boundary conditions. At the inlet, the uniform axial velocity $\mathrm{u}_{\mathrm{o}}$ and initial temperature $\left(T_{0}=293 \mathrm{~K}\right)$ were assumed. The fully developed conditions are assumed at the tube exit section, which means all axial derivatives are zero. A no-slip condition and uniform heat flux are imposed on the tube wall. The continuity, momentum and energy equations subject to above boundary conditions were solved using control volume finite difference scheme. The governing equations are expressed as follows:

$$
\begin{gathered}
\nabla \cdot\left(\rho_{n f} \vec{V}\right)=0 \\
\rho_{n f}(\vec{V} \cdot \nabla \vec{V})=-\nabla P+\nabla \cdot\left(\mu_{e f f} \nabla \vec{V}\right)
\end{gathered}
$$




$$
\nabla \cdot\left(\rho_{n f} C_{p, n f} \vec{V} T\right)=\nabla \cdot\left(k_{e f f} \nabla T\right)
$$

where $\rho_{n f}, \mu_{e f f}, C_{p, n f}, k_{e f f}$ are the density, effective viscosity, specific heat and effective thermal conductivity of the nanofluid, respectively.

\subsection{Thermophysical Properties}

In SPH, the thermophysical properties of the fluids are assumed constant. The dissipation and pressure work are neglected. It was also assumed that the fluid phase and nanoparticles are in thermal equilibrium with zero relative velocity. The effective density $\left(\rho_{e f f}\right)$ and specific heat $\left(C_{p, e f f}\right)$ of the nanofluids were calculated based on the mixture rule. According to Wang et al. [33], specific heat capacity of a particle varies with particle size. Since smaller particles have larger specific surface areas, the influence of surface energy on the effective specific heat capacity increases with a reduction in particle size. To examine the validity of $\rho_{\text {eff }}$ and $C_{p, e f f}$ equations, other similar studies by Pak et al. [34], Ho et al. [35], Das et al. [36] and Khanafer et al. [37] were reviewed. For viscosity, different models can be found in the literature for the effective viscosity of nanofluids as a function of volume fraction. Brinkman et al. [38] presented a viscosity correlation for concentrated suspensions of nanoparticles. Lundgren et al. [39] proposed the viscosity model in form of the Taylor series. Batchelor et al. [40] studied the effect of Brownian motion of the rigid spherical particles on the effective viscosity. For the effective thermal conductivity, Hamilton et al. [41] presented a definition of a two-components mixture. Maxwell [42] proposed a model for solid-liquid mixture with relatively large particles. Buongiorno et al. [43] justified the use of the Maxwell model for calculating the thermal conductivity of water-based nanofluids.

Table 2 shows the summary of the equations reviewed during this study. For computational purposes the equations from Wang et al. [33], Khanafer et al. [37], Batchelor et al. [40] and Purohit et al. [28] were used to calculate the thermophysical properties of the nanofluids.

Table 2. Thermophysical properties equations of nanoparticles.

\begin{tabular}{|c|c|c|}
\hline Properties & Author & Equations \\
\hline Density $\left(\mathrm{kg} / \mathrm{m}^{3}\right)$ & Wang et al. [33] & $\begin{array}{l}\rho_{e f f}=\left(\frac{m}{V}\right)_{e f f}=\frac{m_{b}+m_{p}}{V_{b}+V_{p}}=\frac{\rho_{b} V_{b}+\rho_{p} V_{p}}{V_{b}+V_{p}}=\left(1-\phi_{b}\right) \rho_{b}+\phi_{b} \rho_{p} \\
\phi_{b}=\frac{V_{p}}{V_{f}+V_{p}} \text { is the volume fraction of the nanoparticles }\end{array}$ \\
\hline \multirow{2}{*}{ Specific Heat $(\mathrm{J} / \mathrm{kg} \cdot \mathrm{K})$} & Das et al. [36] & $c_{e f f}=\left(1-\phi_{b}\right) c_{f}+\phi_{b} c_{p}$ \\
\hline & Khanafer et al. [37] & $c_{e f f}=\frac{\left(1-\phi_{b}\right) \rho_{f} c_{f}+\phi_{b} \rho_{p} c_{p}}{\rho_{e f f}}$ \\
\hline \multirow[t]{2}{*}{ Viscosity $(\mathrm{kg} / \mathrm{m} \cdot \mathrm{s})$} & Lundgren [39] & $\mu_{e f f}=\frac{1}{1-2.5 \phi_{b}} \mu_{f}=\left(1+2.5 \phi_{b}+6.25 \phi_{b}^{2}+O\left(\phi_{b}^{3}\right)\right) \mu_{f}$ \\
\hline & Batchelor et al. [40] & $\mu_{e f f}=\left(1+2.5 \phi_{b}+6.2 \phi_{b}^{2}\right) \mu_{f}$ \\
\hline Thermal Conductivity $(\mathrm{W} / \mathrm{m} \cdot \mathrm{K})$ & Hamilton et al. [41] & $k_{e f f}=\frac{k_{f}\left(1-\phi_{p}\right)(d T / d x)_{f}+k_{p} \phi_{p}(d T / d x)_{p}}{\phi_{p}(d T / d x)_{P}+\left(1-\phi_{p}\right)(d T / d x)_{f}}$ \\
\hline
\end{tabular}

The thermophysical properties equations to evaluate the SPD model were expressed as [31]:

$$
\begin{gathered}
k_{e f f}=k_{n f}+k_{\text {disp }} \\
k_{\text {disp }}=C\left(\rho C_{p}\right)_{n f} u d_{p} R \varphi \\
\mu_{e f f}=\mu_{n f}+\mu_{\text {disp }}
\end{gathered}
$$




$$
\mu_{\text {disp }}=\frac{k_{\text {disp }}}{C_{p, b f}} \operatorname{Pr}{ }_{n f}
$$

where, $k_{\text {disp }}$ is the dispersion thermal conductivity, $\mathrm{C}$ is an experimental data constant from Wen et al. [20], $\mathrm{u}$ is the mean velocity, $d_{p}$ is particle diameter, $\mathrm{R}$ is the inner radius, $\mu_{\text {disp }}$ is the dispersion viscosity. The thermophysical properties of the base fluids (water, ethylene glycol and turbine oil) and nanoparticles $\left(\mathrm{Al}_{2} \mathrm{O}_{3}, \mathrm{CuO}, \mathrm{TiO}_{2}, \mathrm{SiO}_{2}, \mathrm{ZnO}\right)$ are specified in Tables 3 and 4 , respectively. These properties were adopted from Sarkar [44], Tertsinidou et al. [45] and Heris et al. [46].

Table 3. Thermophysical properties of different base liquid types.

\begin{tabular}{cccccc}
\hline Base Liquid Type & Density $\mathbf{( \mathbf { k g } / \mathbf { m } ^ { \mathbf { 3 } } )}$ & $\begin{array}{c}\text { Specific Heat } \\
\mathbf{( J / k g} \cdot \mathbf{K})\end{array}$ & $\begin{array}{c}\text { Viscosity } \\
\mathbf{( k g / m} \cdot \mathbf{s})\end{array}$ & $\begin{array}{c}\text { Thermal Conductivity } \\
\mathbf{( W / m} \cdot \mathbf{K})\end{array}$ & $\mathbf{P r}$ \\
\hline Water & 997 & 4170 & $1.00 \times 10^{-3}$ & 0.606 & 6.96 \\
Ethylene-Glycol (EG) & 1111 & 2415 & $1.57 \times 10^{-2}$ & 0.252 & 150.46 \\
Turbine Oil & 868 & 2000 & $2.70 \times 10^{-2}$ & 0.120 & 462.55 \\
\hline
\end{tabular}

Table 4. Thermophysical properties of different nanoparticles types.

\begin{tabular}{|c|c|c|c|}
\hline Nanoparticle Type & Density $\left(\mathrm{kg} / \mathrm{m}^{3}\right)$ & Specific Heat $(\mathrm{J} / \mathrm{kg} \cdot \mathrm{K})$ & Thermal Conductivity $(\mathrm{W} / \mathrm{m} \cdot \mathrm{K})$ \\
\hline $\mathrm{Al}_{2} \mathrm{O}_{3}$ & 3970 & 791 & 40.00 \\
\hline $\mathrm{TiO}_{2}$ & 3900 & 692 & 8.40 \\
\hline $\mathrm{CuO}$ & 6400 & 551 & 32.90 \\
\hline $\mathrm{SiO}_{2}$ & 2200 & 745 & 1.40 \\
\hline $\mathrm{ZnO}$ & 5600 & 495 & 13.00 \\
\hline
\end{tabular}

In this study, the nanofluids effective properties has an important effect on the obtained results. There has been a large number of theories and correlations that have been used and developed for these thermophysical properties with predictions and conclusions that can be different [47]. The thermophysical properties of nanofluids are influenced by the concentration of nanoparticles. The density, viscosity and thermal conductivity of nanofluids increases with increase in nanoparticle concentration. The specific heat capacity decreases with increase in the volume fraction.

\subsection{Grid Independence Test}

The governing equations of mass, momentum and energy were solved using control volume finite difference approach. The semi-implicit method for pressure linked equations was employed to couple pressure and velocity in equations. A second-order upwind scheme was employed for interpolating the parameters. The structured grid distribution was used to discretize the computational domain. To ensure the accuracy and the consistency of computational results, various uniform grids were tested as shown in Table 5. The selected grid for the study calculations consisted of 532 and 30 nodes in the axial and radial directions, respectively. The numerical computations were considered converged, when the residual summed over all the computational nodes at $i$ th iteration, $R_{j}^{i}$, satisfies the following criterion: $\left(R_{j}^{i} / R_{j}^{m}\right) \leq 10^{6}$, where $R_{j}^{m}$ denotes the maximum residual value of $j$ variable after $m$ iterations, and $j$ is applied for pressure, velocity and temperature.

Table 5. Mesh independency test.

\begin{tabular}{cccccccc}
\hline Grid Size & $\mathbf{N u}$ & Grid Size & Nu & Grid Size & Nu & Grid Size & Nu \\
\hline $534 \times 10$ & 5.80 & $534 \times 20$ & 5.85 & $534 \times 30$ & 5.94 & $534 \times 40$ & 5.94 \\
\hline
\end{tabular}

The local and average HTC's were calculated using Equations (8) and (9), respectively.

$$
h_{x}=\frac{q^{\prime \prime}}{T_{w}(x)-T_{m}(x)}
$$




$$
h_{\text {avg }}=\frac{1}{L} \int_{0}^{L} h(x) d x
$$

The Nusselt number $(N u)$, was defined as:

$$
N u(x)=\frac{\left(h_{x} D\right)}{k}
$$

The wall and fluid temperatures and the heat flux were computed to calculate the convective HTC. For constant heat flux, the fluid mean temperature $\left(T_{m}\right)$ was computed as follows:

$$
T_{m}=\frac{1}{v_{\operatorname{avg}} A} \int_{0}^{A} u T d A
$$

\section{Results \& Discussion}

An extensive number of numerical simulations were performed to determine the HTC enhancement of laminar nanofluids. For validation purpose, the present results of the $\mathrm{Nu}$ for straight tube were compared with the correlation $\left(\mathrm{Nu}=0.086 \mathrm{Re}^{0.55} \mathrm{Pr}^{0.5}\right)$ of Maïga et al. [21] and the computational results of Singh et al. [48] for constant heat flux condition. Figure 1a shows a good agreement of the present results with the literature [21,48] for water-based $\mathrm{Al}_{2} \mathrm{O}_{3}$ nanofluid at $\phi_{b}=1 \%$. The $\mathrm{Nu}$ results were also validated for constant wall temperature condition as shown in Figure $1 \mathrm{~b}$. It may be noted that there is a good agreement between the present results and results predicted by Maigga et al. [21] $\left(\mathrm{Nu}=0.28 R e^{0.35} \mathrm{Pr}^{0.36}\right)$, for the $\mathrm{Al}_{2} \mathrm{O}_{3}$-water based nanofluid with $\phi_{b}=4 \%$.

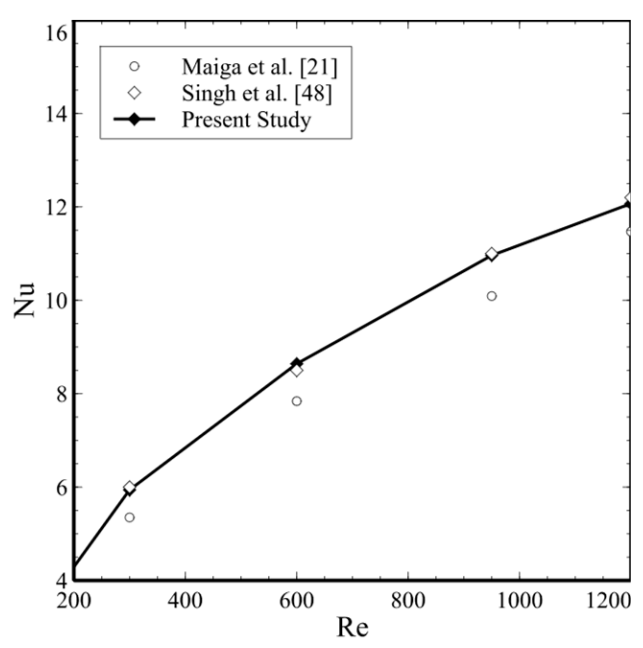

(a)

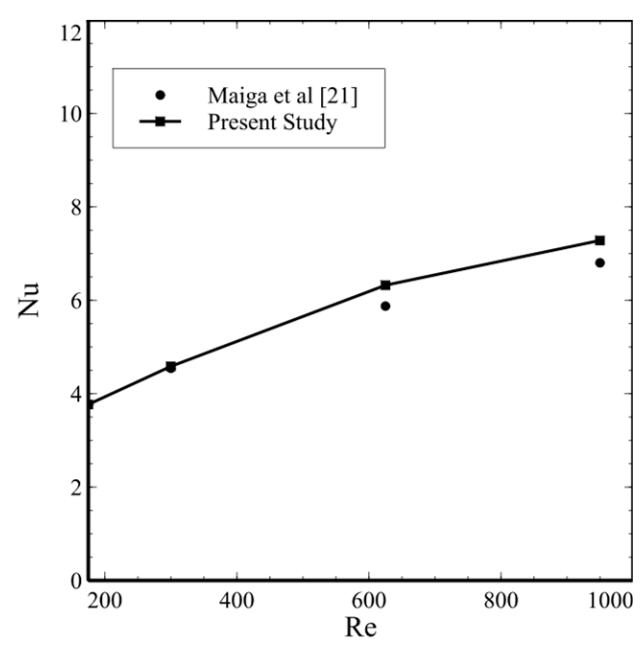

(b)

Figure 1. Comparison of $\mathrm{Nu}$ for $\mathrm{Al}_{2} \mathrm{O}_{3}$-water nanofluid. (a) Constant heat flux condition at $\phi_{b}=1 \%$.

(b) Constant wall temperature condition at $\phi_{b}=4 \%$.

In this study, six different cases with different combinations of the geometry, nanoparticles concentration and base fluids were considered as shown in Table 6. It may be noted from Table 6 that three different base fluids and five different nanofluids with a wide range of particle volume fractions $\left(0 \leq \phi_{b} \leq 10 \%\right)$ are considered for the detailed investigation.

\subsection{Case 1: Water-Based Nanofluid in Straight Tube with Constant Heat Flux Using SPH}

In the first case, water-based nanofluids with the constant wall heat flux $\left(q_{w}^{\prime \prime}=10,000 \mathrm{~W} / \mathrm{m}^{2}\right)$ were considered. Figure 2 shows the results for the fluid temperature in the radial direction and the wall temperature at the constant values of $\operatorname{Re}=500$ and $T_{o}=293.15 \mathrm{~K}$. It may be noted from Figure 2a, 
that the fluid temperature decreases with an increase of the nanoparticle concentration from 0 to $10 \%$, especially near the tube wall, suggesting a higher heat transfer rate (above 10\%) with nanoparticles.

Table 6. Cases considered to determine the heat transfer coefficient (HTC) enhancement of laminar nanofluids. SPH: single-phase model; SPD: the single-phase dispersion model.

\begin{tabular}{ccccccc}
\hline Case & Base Fluid & Nanoparticles & Boundary Condition & Model & vol\% & Geometry \\
\hline 1 & Water & $\mathrm{Al}_{2} \mathrm{O}_{3}, \mathrm{TiO}_{2}, \mathrm{CuO}, \mathrm{SiO}_{2}, \mathrm{ZnO}$ & Constant Heat Flux & $\mathrm{SPH}$ & $0-10$ & $\mathrm{~S}$. Tube \\
2 & EG & $\mathrm{Al}_{2} \mathrm{O}_{3}, \mathrm{TiO}_{2}, \mathrm{CuO}, \mathrm{SiO}_{2}, \mathrm{ZnO}$ & Constant Heat Flux & $\mathrm{SPH}$ & $0-10$ & $\mathrm{~S}$. Tube \\
3 & Turbine Oil & $\mathrm{Al}_{2} \mathrm{O}_{3}, \mathrm{TiO}_{2}, \mathrm{CuO}, \mathrm{SiO}_{2}, \mathrm{ZnO}$ & Constant Heat Flux & $\mathrm{SPH}$ & $0-10$ & S. Tube \\
4 & Water & $\mathrm{Al}_{2} \mathrm{O}_{3}, \mathrm{TiO}_{2}, \mathrm{CuO}, \mathrm{SiO}_{2}, \mathrm{ZnO}$ & Constant Temperature & $\mathrm{SPH}$ & $0-10$ & S. Tube \\
5 & Water & $\mathrm{Al}_{2} \mathrm{O}_{3}, \mathrm{TiO}_{2}, \mathrm{CuO}, \mathrm{SiO}_{2}, \mathrm{ZnO}$ & Constant Heat Flux & $\mathrm{SPH}$ & $0-10$ & Microtube \\
6 & Water & $\mathrm{Al}_{2} \mathrm{O}_{3}, \mathrm{TiO}_{2}, \mathrm{CuO}, \mathrm{SiO}_{2}, \mathrm{ZnO}$ & Constant Heat Flux & $\mathrm{SPD}$ & $0-10$ & S. Tube \\
\hline
\end{tabular}

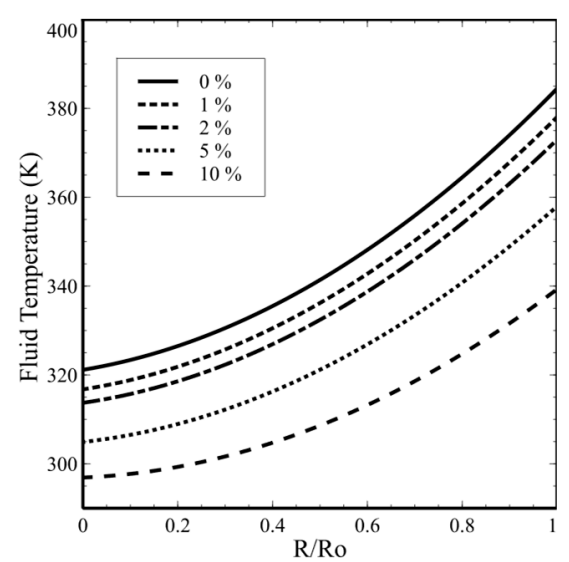

(a)

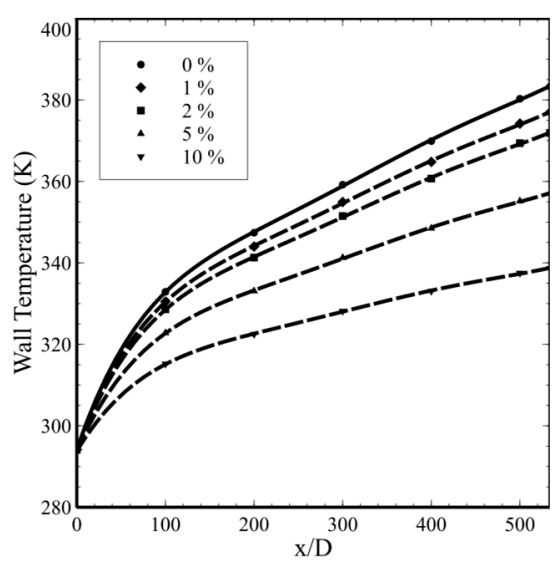

(b)

Figure 2. Effect of nanoparticle concentration in tube flow: (a) fluid temperature profiles at tube exit; (b) axial development of wall temperature.

Figure $2 \mathrm{~b}$ demonstrates the diminution of the wall temperature at different nanoparticle concentrations. The wall temperature decreases by $40 \mathrm{~K}$ for the $\mathrm{Al}_{2} \mathrm{O}_{3}$-water nanofluid with nanoparticle concentrations from 0 to $10 \%$. The diminution in temperature reflects a better heat transfer rate at the tube wall. These effects may be explained by the fact that with the presence of the nanoparticles, the thermal properties of the resulting mixture have become more important as the product of $\rho C_{p}$ and the thermal conductivity have increase with respect to pure water.

Figure 3 shows the effect of nanoparticle concentration on the fluid mean temperature and wall temperature in axial direction. It may be noted from Figure $3 a$ that the fluid mean temperature decreases with an increase in the value of $\phi_{b}$. The decrease in the fluid mean temperature is caused mainly due to the higher thermal conductivity (up to $32 \%$ ) of the $\mathrm{Al}_{2} \mathrm{O}_{3}$-water nanofluid. The radial, wall and fluid mean temperatures demonstrate that $\mathrm{Al}_{2} \mathrm{O}_{3}$-water nanofluid offers a higher thermal capacity as compared to the water. It may also be observed that at the higher thermal conductivity, the wall-to-fluid heat transfer is more important as it augments the heat transfer rate. Three nanoparticles $\left(\mathrm{Al}_{2} \mathrm{O}_{3}, \mathrm{TiO}_{2}\right.$ and $\left.\mathrm{CuO}\right)$ with two different concentrations $\left(\phi_{b}=1 \%\right.$ and $\left.\phi_{b}=10 \%\right)$ were considered to investigate the thermal efficiency of the nanofluids with increase in the particle concentrations as shown in Figure $3 b$.

For the higher nanoparticle concentration $\left(\phi_{b}=10 \%\right)$, the wall temperature for $\mathrm{Al}_{2} \mathrm{O}_{3}$-water nanofluid is lower than the $\mathrm{TiO}_{2}$-water and CuO-water nanofluids. This lower temperature can be explained with the higher values of thermal conductivity which is $4 \%$ higher as compared to $\mathrm{TiO}_{2}$-water and $1 \%$ higher as compared to $\mathrm{CuO}$-water. The results revealed that $\mathrm{Al}_{2} \mathrm{O}_{3}$-water nanofluids will have a higher transfer coefficient (at least $1 \%$ ) than the other two nanofluids considered. The nanoparticles concentration has effect on heat transfer performance. A larger number of nanoparticles in the base-fluid increases the thermal conductivity of the nanofluid but it is accompanied with higher values 
of the wall shear stress. Although, the use of nanofluids has heat transfer enhancement capabilities due to their increase viscosity, they will also increase friction/pressure losses. For example, Maïga et al. [21] found that there is a 2.5-fold increase in the wall shear stress with a $\phi_{b}=5 \%$ for an $\mathrm{Al}_{2} \mathrm{O}_{3}$-water nanofluid. Because of the friction/pressure losses, the benefits of the higher transfer rates versus the corresponding and drastic increases in viscosity must be considered.

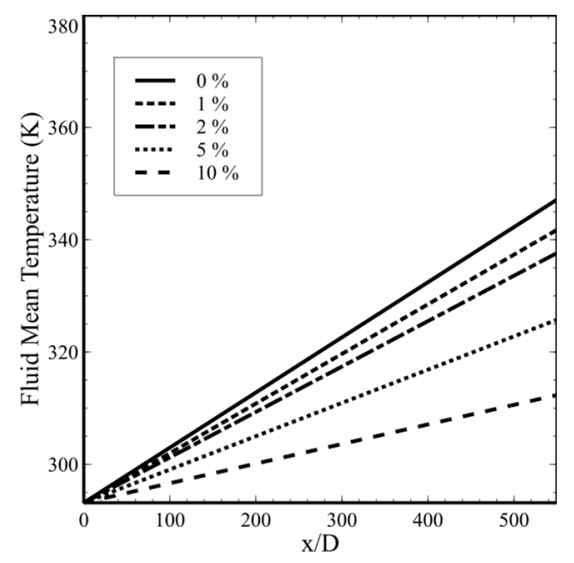

(a)

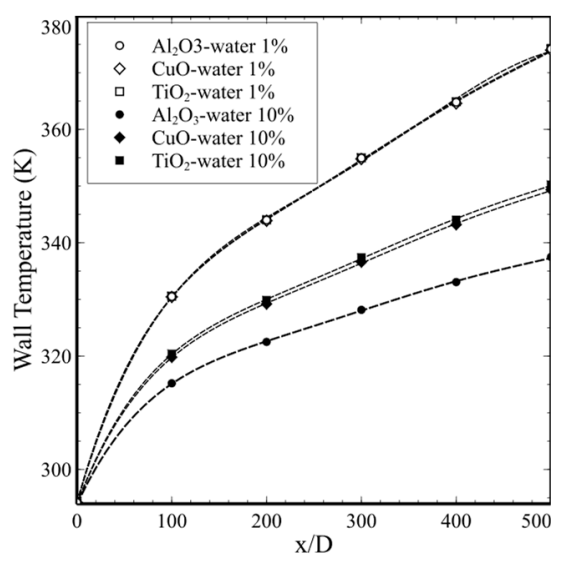

(b)

Figure 3. Effect of nanoparticle concentration in tube flow: (a) axial development of $\mathrm{T}_{\mathrm{m}}$; (b) axial development of wall temperatures.

In this study, two different nanoparticle concentrations $\left(\phi_{b}=1 \%\right.$ and $\left.\phi_{b}=4 \%\right)$ of the water-based $\mathrm{Al}_{2} \mathrm{O}_{3}$ nanofluid were used to determine the effect of the nanoparticle concentration. Figure 4 shows that the $\mathrm{Nu}$ increases with an increase in nanoparticle concentration for any given value of Re. This is mainly because the nanoparticles increase the thermal conductivity of the base fluid and, hence, augments the convective heat transfer. At low Re (below 100) the Nu is 2.2 times higher for $\phi_{b}=4 \%$ as compared to $\phi_{b}=1 \%$. For high Re (above 1000) Nu increases less than $10 \%$. Considering this reduction of $\mathrm{Nu}$ and the increases of the wall shear stresses using more than $\phi_{b}=5 \%$, a higher nanoparticle concentration would have to be determined by the specific application.

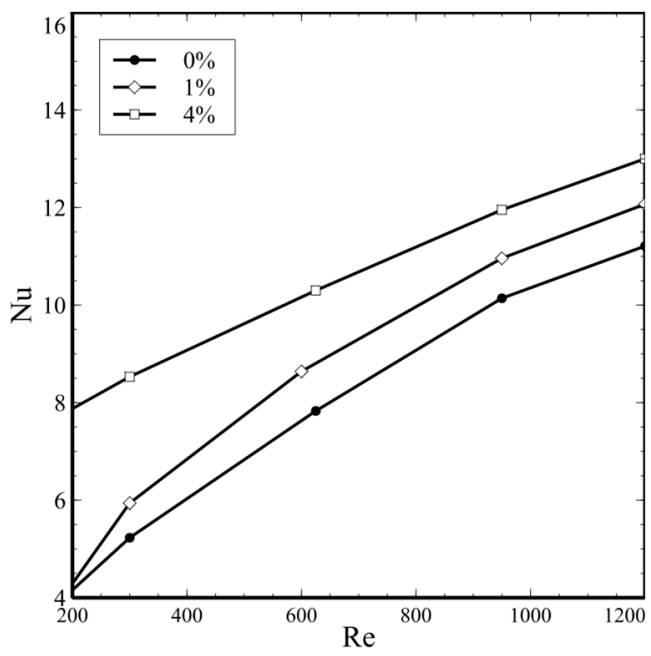

Figure 4. Comparison of $\mathrm{Nu}$ for an $\mathrm{Al}_{2} \mathrm{O}_{3}$-water nanofluid at $\phi_{b}=0 \%, 1 \%$ and $4 \%$.

Figure 5 shows a comparison of $\mathrm{Nu}$ for the different nanoparticles considered. Among the nanoparticles studied $\mathrm{Al}_{2} \mathrm{O}_{3}, \mathrm{TiO}_{2}, \mathrm{CuO}, \mathrm{SiO}_{2}, \mathrm{ZnO}$ there is evidence that the $\mathrm{Al}_{2} \mathrm{O}_{3}$ nanofluid has a marginally higher value (by $4 \%$ ) of $\mathrm{Nu}$ for the $\mathrm{Al}_{2} \mathrm{O}_{3}$-water based nanofluid as compared to the $\mathrm{ZnO}$-water nanofluid. This enhancement in the $\mathrm{Nu}$ is relatively lower as the $\mathrm{Pr}$ of all the selected 
nanofluids are in the range of 6.7 to 7.3 at $\phi_{b}=4 \%$. The $\mathrm{Nu}$ of $\mathrm{SiO}_{2}$-water nanofluid was the second highest since $\mathrm{SiO}_{2}$ nanofluid has the highest average velocity among the fluids because of the lowest value of density $\left(\rho=1046 \mathrm{~kg} / \mathrm{m}^{3}\right)$. The result indicate that the fluid velocity plays a role on the heat transfer.

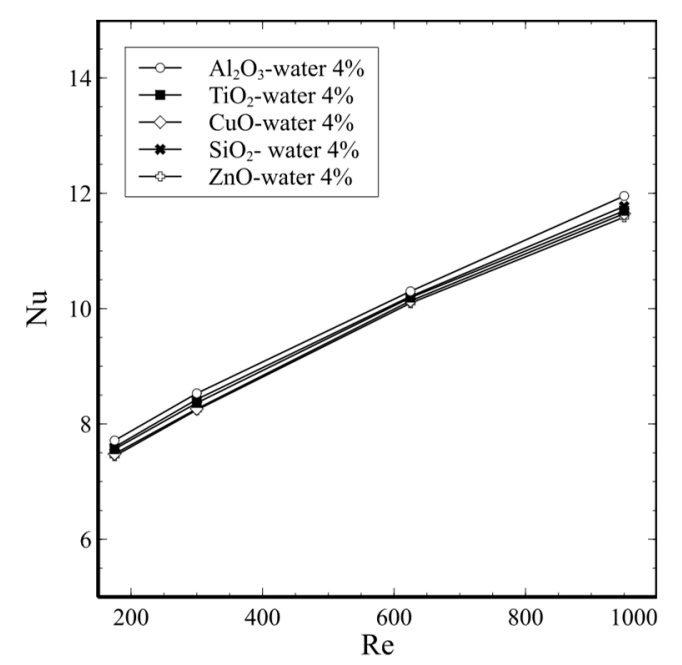

Figure 5. Comparison of $\mathrm{Nu}$ for water-based nanofluids at $\phi_{b}=4 \%$.

\subsection{Case 2: Ethylene Glycol-Based Nanofluid in Straight Tube with Constant Heat Flux Using SPH}

This case considers ethylene-glycol (EG)-based nanofluids with equal parameters as previous case for comparison purposes. Figure 6 shows the axial development of the wall temperatures at lower $\left(\phi_{b}=1 \%\right)$ and higher $\left(\phi_{b}=10 \%\right)$ values of nanoparticle concentration. For the lower nanoparticle concentration $\left(\phi_{b}=1 \%\right)$, the $\mathrm{T}_{\mathrm{W}}$ with $\mathrm{Al}_{2} \mathrm{O}_{3}$-EG nanofluid is approximately the same to $\mathrm{TiO}_{2}$-EG and CuO-EG because of the marginal difference in the values of the thermal conductivities $(0.3 \%$ higher as compared to $\mathrm{TiO}_{2}$-EG nanofluid and $0.2 \%$ as compared to $\mathrm{CuO}-\mathrm{EG}$ nanofluid). For the higher nanoparticle concentration $\left(\phi_{b}=10 \%\right)$, the $\mathrm{T}_{\mathrm{w}}$ decreases by $15 \mathrm{~K}$ for the $\mathrm{Al}_{2} \mathrm{O}_{3}$-EG nanofluid due to the movement of the nanoparticles at a higher Re, which results in a higher thermal efficiency.

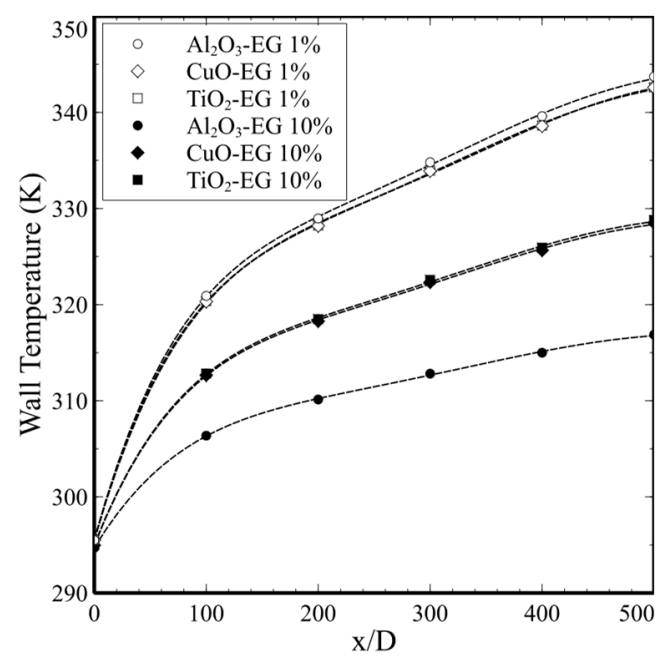

Figure 6. Effect of nanoparticle concentration in tube flow: axial development of wall temperatures. 


\subsection{Case 3: Turbine Oil-Based Nanofluid in Straight Tube with Constant Heat Flux Using SPH}

Case 3 considers turbine oil-based nanofluids with the same parameters used in previous two cases. The effect of base fluid was investigated using three different base fluids viz. water, ethylene glycol and turbine oil with the same nanoparticle $\left(\mathrm{Al}_{2} \mathrm{O}_{3}, \phi_{b}=4 \%\right)$ as shown in Figure 7.

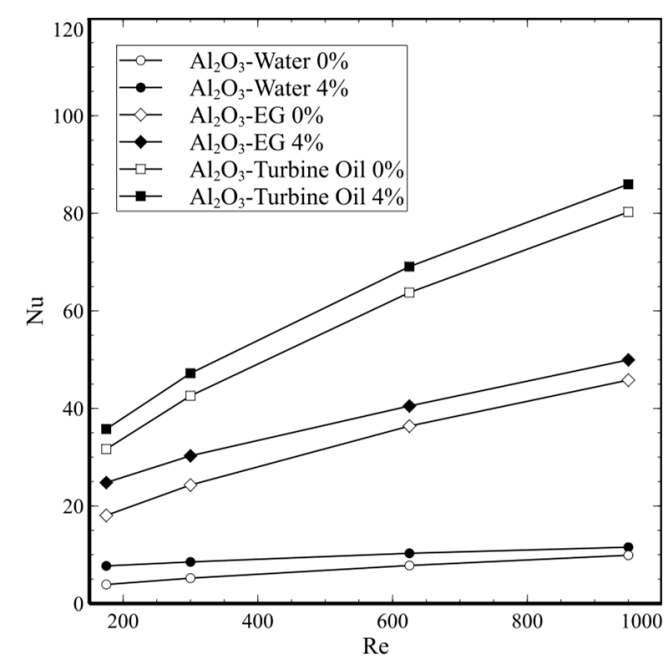

Figure 7. Comparison of $\mathrm{Nu}$ for $\mathrm{Al}_{2} \mathrm{O}_{3}$-water, $\mathrm{Al}_{2} \mathrm{O}_{3}$-EG and $\mathrm{Al}_{2} \mathrm{O}_{3}$-turbine oil at $\phi_{b}=4 \%$.

All the nanofluids $\left(\mathrm{Al}_{2} \mathrm{O}_{3}\right.$-water, $\mathrm{Al}_{2} \mathrm{O}_{3}$-EG and $\mathrm{Al}_{2} \mathrm{O}_{3}$-turbine oil) significantly enhance the value of $\mathrm{Nu}$ as compared to the any base fluid alone. It may be noted that the $\mathrm{Nu}$ enhanced by $16 \%$ for $\mathrm{Al}_{2} \mathrm{O}_{3}$-water nanofluid as compared to the water, $12 \%$ for the $\mathrm{Al}_{2} \mathrm{O}_{3}$-EG nanofluid as compared to ethylene glycol and $8 \%$ for the $\mathrm{Al}_{2} \mathrm{O}_{3}$-turbine oil when compared to turbine oil. The $\mathrm{Nu}$ enhancement is due to similar reasons as previous two cases.

The heat transfer enhancement using nanofluids may be affected by several factors such as Brownian motion, Brownian diffusion, dispersion and friction force between the fluid and nanoparticles. Because of this several factors, the heat characteristics of nanofluids are dependent on the properties of the base liquid, the dispersed phases and particle concentration. Therefore, the general form of the Nu yields:

$$
N u=f\left(\operatorname{Re}, \operatorname{Pr}, \frac{k_{p}}{k_{b f}}, \frac{\left(\rho C_{p}\right)_{p}}{\left(\rho C_{p}\right)_{b f}}, \phi_{b}\right)
$$

In the present study a new correlation for $\mathrm{Nu}$ (Equation (13)) has been developed covering a wide range of the nanoparticle concentration $\left(0 \% \leq \phi_{b} \leq 10 \%\right)$ and Prandtl number (6.0-500) under the constant heat flow and laminar flow conditions $(25<\operatorname{Re}<1500)$.

Figure 8 shows the comparison between the present computed $\mathrm{Nu}$ results, the experimental results and the computed data from the literature with the present proposed correlation (Equation (13)). It may be observed from Figure 8 that the present results of $\mathrm{Nu}$ are in good agreement with the experimental results developed by Wen \& Ding [20], Anoop et al. [23], Heris et al. [46], Heris et al. [49] and with the computational results from Maïga et al. [21].

$$
N u=0.4381 \operatorname{Re}^{0.36} \operatorname{Pr}^{0.42}
$$




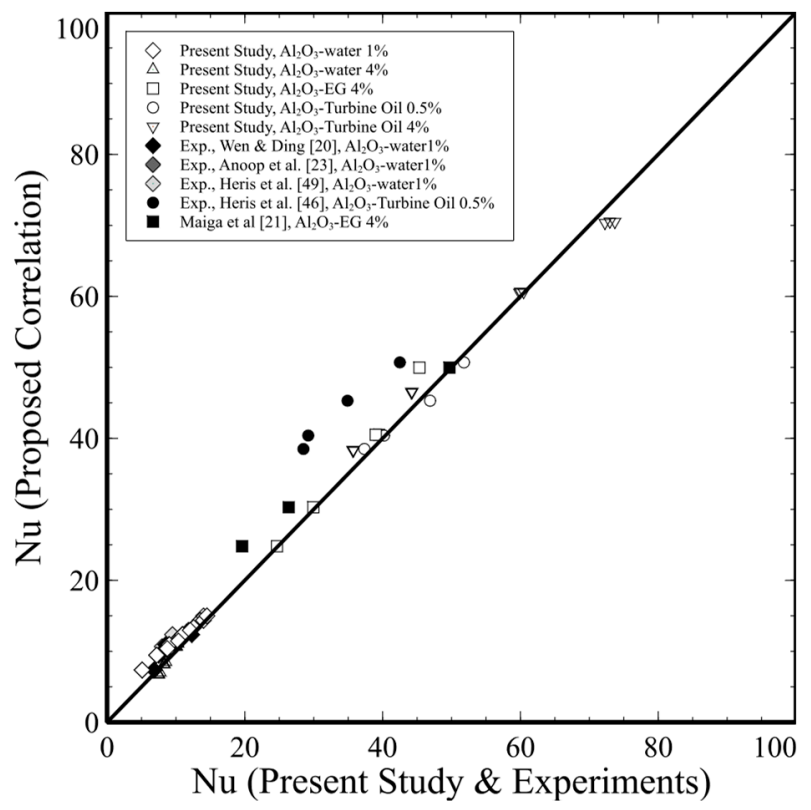

Figure 8. Proposed correlation vs computed results and experiments of $\mathrm{Nu}$ in a straight tube.

\subsection{Case 4: Water-Based Nanofluid in Straight Tube with Constant Wall Temperature Using SPH}

In this case water-based nanofluids are used at a constant wall temperature $\left(\mathrm{T}_{\mathrm{W}}=313.15 \mathrm{~K}\right)$ condition with an inlet fluid temperature of $\mathrm{T}_{\mathrm{O}}=293.15 \mathrm{~K}$, at $\mathrm{Re}=500$. Figure 9 demonstrates the effect of the nanoparticle concentration on the $\mathrm{T}_{\mathrm{m}}$ for constant wall temperature condition.

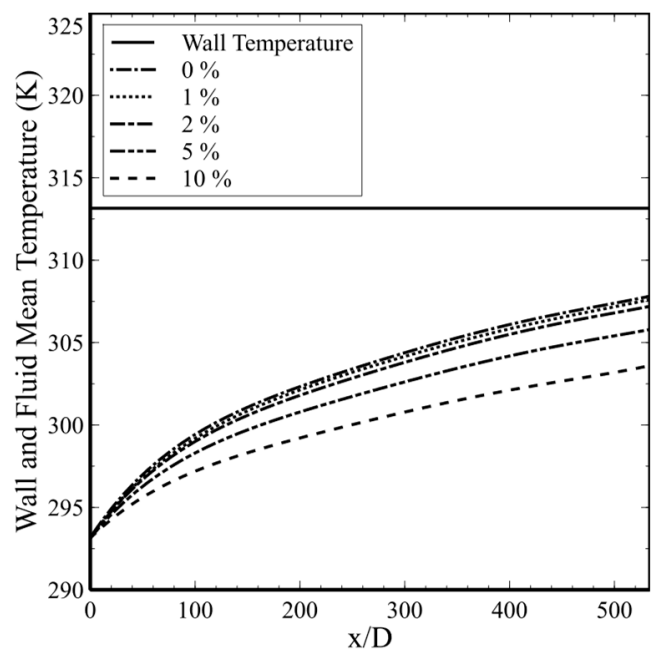

Figure 9. Effect of nanoparticle concentration in tube flow: axial development of wall and $\mathrm{T}_{\mathrm{m}}$.

It can be observed that the $\mathrm{T}_{\mathrm{m}}$ decreases with increase in the concentration of nanoparticles due to the improved heat capacity (up to $23 \%$ ). The $\mathrm{T}_{\mathrm{m}}$ for a highest nanoparticle concentration $\left(\phi_{b}=10 \%\right.$ ) was lower by $10 \mathrm{~K}$ as compared to the water. The diminution of temperature reflects the improvement in the thermal properties of the resulting mixture caused by the Brownian motion. The effect of the different water based nanofluids was investigated using different nanoparticles viz $\mathrm{Al}_{2} \mathrm{O}_{3}, \mathrm{TiO}_{2}$, $\mathrm{CuO}, \mathrm{SiO}_{2}$ and $\mathrm{ZnO}$, as shown in Figure 10a. It may be noted that the $\mathrm{Al}_{2} \mathrm{O}_{3}$-water nanofluid has a higher heat transfer rate than all other nanofluids. The enhancement in $\mathrm{Nu}$ for the $\mathrm{Al}_{2} \mathrm{O}_{3}$-water is $14 \%$ higher as compared to $\mathrm{ZnO}$-water nanofluid. Figure $10 \mathrm{~b}$ shows the overall effect of the different base fluids on $\mathrm{Nu}$ for constant temperature boundary condition. The $\mathrm{Nu}$ at $\mathrm{Re}=950$ enhanced by $16 \%$ for $\mathrm{Al}_{2} \mathrm{O}_{3}$-water nanofluid as compared to water, $10 \%$ for $\mathrm{Al}_{2} \mathrm{O}_{3}$-EG nanofluid as compared to ethylene 
glycol and $8 \%$ for $\mathrm{Al}_{2} \mathrm{O}_{3}$-turbine oil nanofluid as compared to turbine oil. The enhancement in the $\mathrm{Nu}$ is mainly due to the thermophysical properties of the nanoparticles.

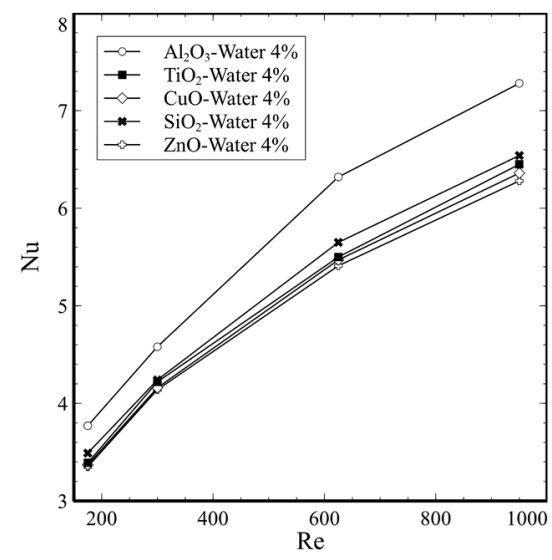

(a)

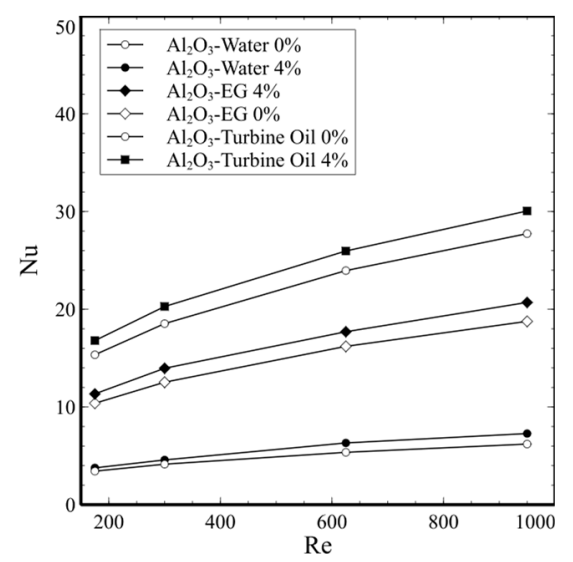

(b)

Figure 10. Comparison of $\mathrm{Nu}$ for: (a) $\mathrm{Al}_{2} \mathrm{O}_{3}$-water, $\mathrm{TiO}_{2}$-water, $\mathrm{CuO}$-water, $\mathrm{SiO}_{2}$-water and $\mathrm{ZnO}$-water and at $\phi_{b}=4 \%$; (b) $\mathrm{Al}_{2} \mathrm{O}_{3}$-water, $\mathrm{Al}_{2} \mathrm{O}_{3}$-EG and $\mathrm{Al}_{2} \mathrm{O}_{3}$-turbine oil at $\phi_{b}=4 \%$.

For the average $\mathrm{Nu}$ in a straight tube with constant wall temperature a new correlation (Equation (14)) is proposed by fitting the data obtained from the numerical simulations. The correlation covers a wide range of the nanoparticle concentration $\left(0 \% \leq \phi_{b} \leq 10 \%\right)$ and Prandtl number (6.0-500) under the laminar flow condition $(25<\mathrm{Re}<1500)$. Figure 11 shows the comparison between the present computed $\mathrm{Nu}$ results, with the experimental results from Heris et al. [22], Ting et al. [50] and the computed data from Maïga et al. [21] with the present proposed correlation (Equation (14)). A good agreement was attained between the computed and previous experimental work with the predicted values of the $\mathrm{Nu}$ with a variation of $\pm 5 \%$.

$$
N u=0.257 \operatorname{Re}^{0.37} \operatorname{Pr}^{0.36}
$$

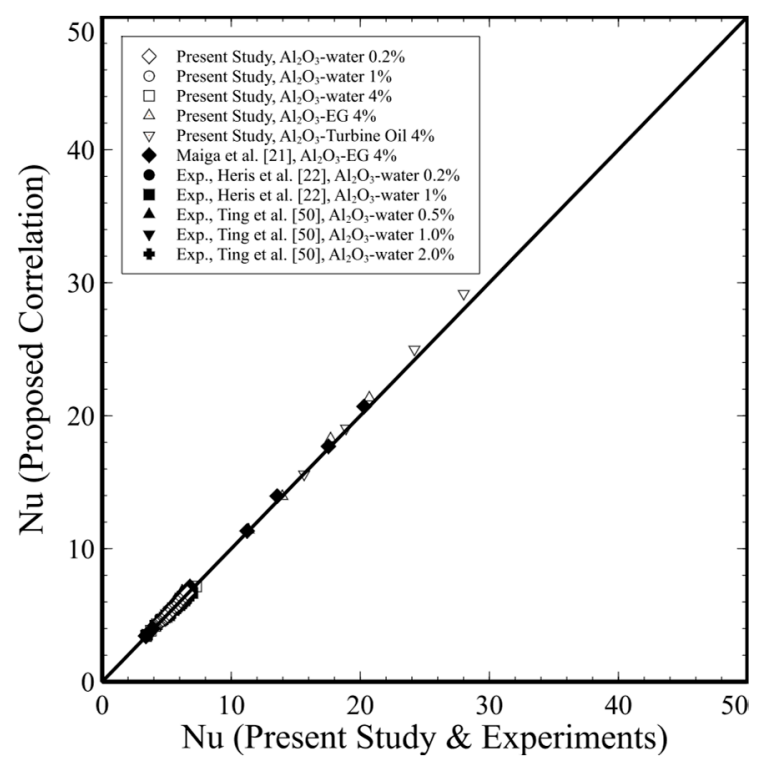

Figure 11. Proposed correlation vs computed results and experiments of $\mathrm{Nu}$ in a straight tube.

\subsection{Case 5: Water-Based Nanofluid in Straight Microtube with Constant Heat Flux Using SPH}

In case 5 , all the different nanofluids $\mathrm{Al}_{2} \mathrm{O}_{3}$-water, $\mathrm{TiO}_{2}$-water, $\mathrm{CuO}$-water, $\mathrm{SiO}_{2}$-water and $\mathrm{ZnO}$-water are used to investigate the $\mathrm{Nu}$ in a straight microtube with a length of $0.3 \mathrm{~m}$ and an inner 
diameter $\left(\mathrm{d}_{\mathrm{t}}\right)$ of $0.5 \mathrm{~mm}$. Results from the numerical simulation were compared with Shah's [51] correlation (Equation (15)) for validation purpose. A good agreement can be seen in between the present computed results of $\mathrm{Nu}$ with the predicted values from Shah's correlation, as shown in Figure 12.

$$
N u=\left[\begin{array}{c}
1.953\left(\operatorname{Re} \operatorname{Pr} \frac{D}{L}\right)^{\frac{1}{3}} \operatorname{Re} \operatorname{Pr} \frac{D}{L} \geq 33.3 \\
4.364+0.0722 \operatorname{Re} \operatorname{Pr} \frac{D}{L} \operatorname{Re} \operatorname{Pr} \frac{D}{L}<33.3
\end{array}\right.
$$

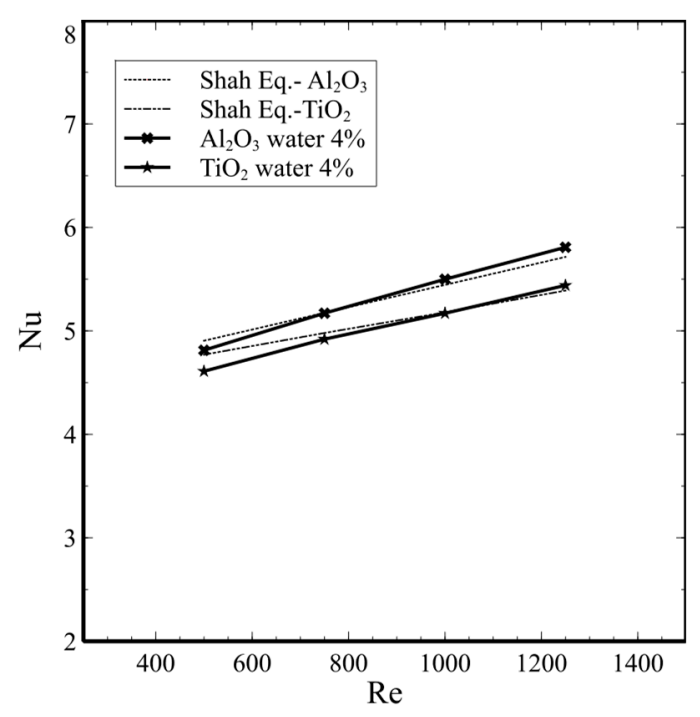

Figure 12. Comparison of $\mathrm{Nu}$ with literature: $\mathrm{Al}_{2} \mathrm{O}_{3}$-water nanofluid at $\phi_{b}=4 \%$.

It may be noted from Figure 13a,b that similar to the straight tube results, the wall temperature as well as fluid mean temperature in the straight microtube also decreases with increase in the nanoparticle concentration. The decrease in the temperatures of the wall and the fluid will result in a better heat transfer.

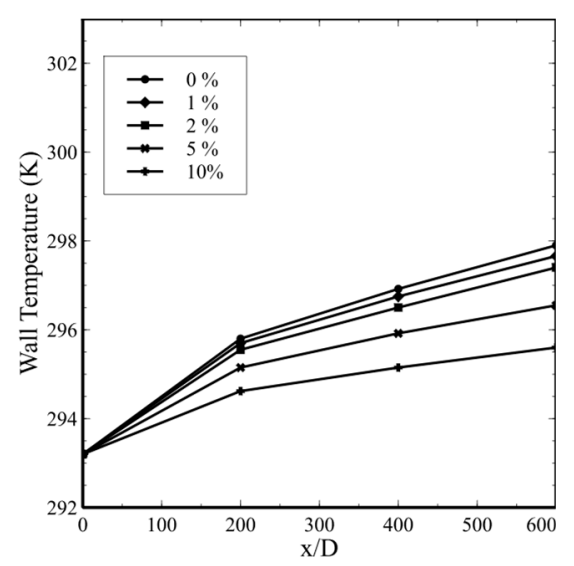

(a)

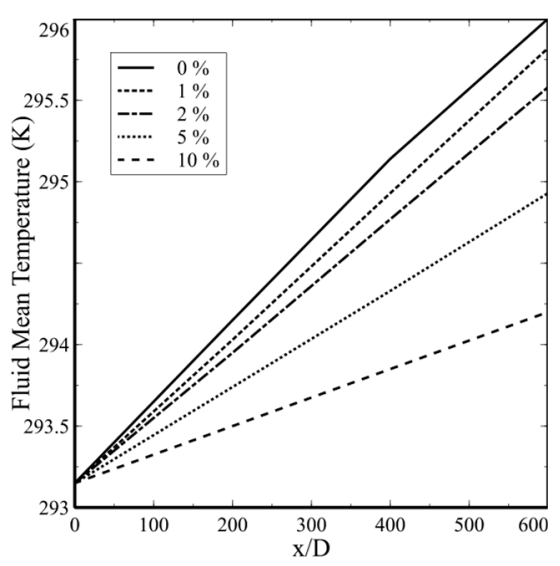

(b)

Figure 13. Effect of nanoparticle concentration in tube flow: (a) axial development of wall temperatures; (b) fluid mean temperatures for $\mathrm{Al}_{2} \mathrm{O}_{3}$-water.

Figure 14a shows the effect of the different type of nanoparticles for a water-based nanofluid. The $\mathrm{Al}_{2} \mathrm{O}_{3}$-water nanofluid has a better heat transfer enhancement as compared to that of all the other nanoparticles due to the higher thermal conductivity. Figure $14 \mathrm{~b}$ shows the $\mathrm{Nu}$ for different fluids at the same $\operatorname{Re}=950$. The turbine oil-based nanofluid has the higher $\mathrm{Nu}$, however it is not the nanofluid with the higher enhancement. 


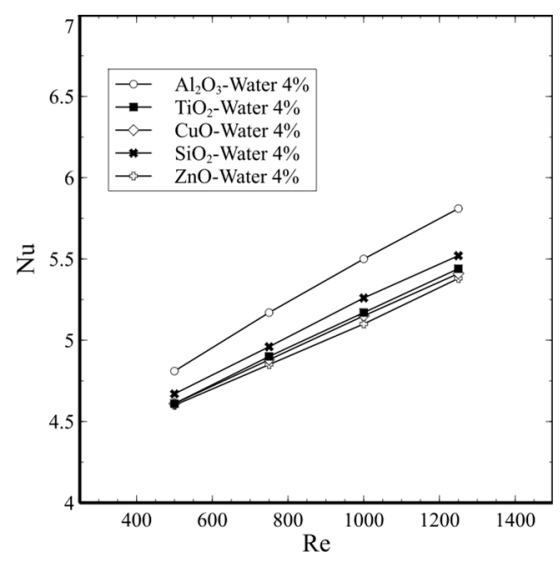

(a)

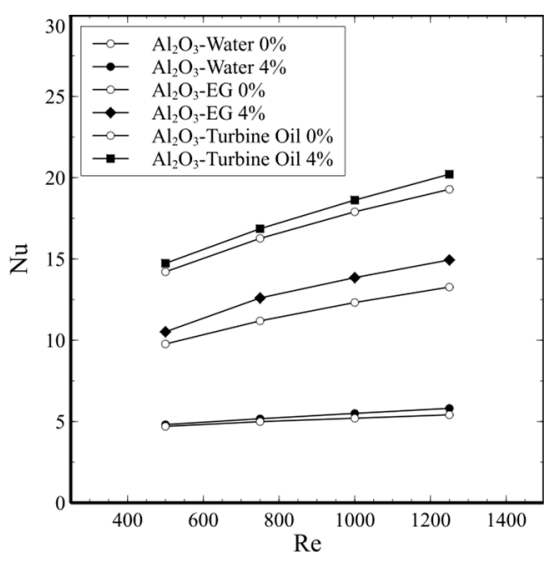

(b)

Figure 14. Comparison of $\mathrm{Nu}$ for (a) water-based nanofluids at $\phi_{b}=4 \%$; (b) $\mathrm{Al}_{2} \mathrm{O}_{3}$-water, $\mathrm{Al}_{2} \mathrm{O}_{3}$-EG and $\mathrm{Al}_{2} \mathrm{O}_{3}$-turbine oil at $\phi_{b}=4 \%$.

The $\mathrm{Nu}$ enhancement was $6 \%$ for $\mathrm{Al}_{2} \mathrm{O}_{3}$-water compared to water, $12 \%$ for $\mathrm{Al}_{2} \mathrm{O}_{3}$-EG compared to ethylene glycol and $5 \%$ for $\mathrm{Al}_{2} \mathrm{O}_{3}$-turbine oil compared to turbine oil. Based on these results, it may be concluded that ethylene glycol-based nanofluids are the best choice for heat transfer enhancement at the same Re and $\phi_{b}$.

For the average $\mathrm{Nu}$ in a microtube with constant heat flux a new correlation (Equation (16)) is proposed by fitting the data obtained from the numerical simulations. The correlation covers a wide range of the process parameters $\left(25<\operatorname{Re}<1500,0<\phi_{b}<10,6<\operatorname{Pr}<500\right)$ under the laminar flow condition.

Figure 15 shows the comparison between the present $\mathrm{Nu}$ results along with the experiments from Haghighi et al. [52] and the computed data from Salman et al. [53] with the present proposed correlation (Equation [16]). The predicted values of $\mathrm{Nu}$ are in good agreement (variation of $\pm 5 \%$ ) with the computed values and the previous experimental results.

$$
N u=0.4561 \operatorname{Re}^{0.27} \operatorname{Pr}^{0.30}
$$

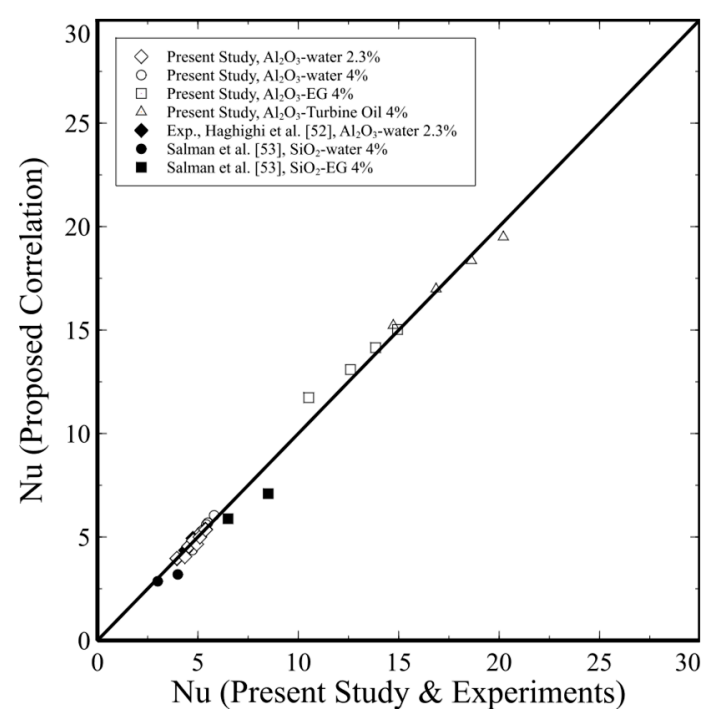

Figure 15. Proposed correlation vs computed results and experiments of $\mathrm{Nu}$ in a straight tube.

\subsection{Case 6: Water-Based Nanofluid in Straight Tube with Constant Heat Flux Using SPD}

Case 6 purpose is to simulate the nanofluid flow for a constant heat flux condition in a straight tube using the SPD. Figure 16 shows a comparison of the computed Nu results using SPD and SPH. 
It may be noted that the $\mathrm{Nu}$ increases with the increase of the Re. The SPD shows a higher Nu due to a higher thermal conductivity and viscosity of the nanofluid. Results of the SPD model show agreement with Liu et al. [31], where the Nu of the nanofluid is better predicted in the SPD than in the SPH. The SPD model is recommended as the appropriate model for predicting the heat transfer characteristics of nanofluid flow in a straight tube.

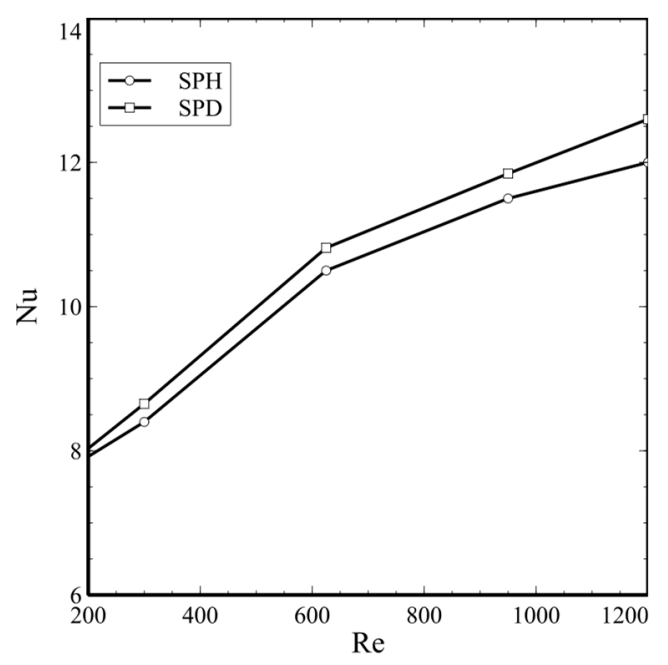

Figure 16. Comparison of $\mathrm{Nu}$ with literature: $\mathrm{Al}_{2} \mathrm{O}_{3}$-water nanofluid at $\phi_{b}=4 \%$ for SPH and SPD.

\section{Conclusions}

In the present study, heat transfer of different nanofluid types were investigated using two configurations: straight tube and straight microtube. Both geometries presented an enhancement in the $\mathrm{Nu}$ using nanofluids. In case of the straight tube with $\phi_{b}=4 \%$, the $\mathrm{Nu}$ increases $16 \%$ for $\mathrm{Al}_{2} \mathrm{O}_{3}$-water as compared to water, $12 \%$ for $\mathrm{Al}_{2} \mathrm{O}_{3}$-EG as compared to $\mathrm{EG}$ and $8 \%$ for $\mathrm{Al}_{2} \mathrm{O}_{3}$-turbine oil as compared to turbine oil. For the straight microtube with $\phi_{b}=4 \%$ the Nu increases $6 \%$ for $\mathrm{Al}_{2} \mathrm{O}_{3}$-water as compared to water, $12 \%$ for $\mathrm{Al}_{2} \mathrm{O}_{3}$-EG as compared to ethylene glycol and $5 \%$ for $\mathrm{Al}_{2} \mathrm{O}_{3}$-turbine oil as compared to turbine oil.

Despite the better heat transfer enhancement in $\mathrm{Al}_{2} \mathrm{O}_{3}-\mathrm{EG}$ and $\mathrm{Al}_{2} \mathrm{O}_{3}$-turbine oil it is imperative to consider the associated higher values of the wall shear stress (e.g., quadruple of the corresponding based fluid for an $\mathrm{Al}_{2} \mathrm{O}_{3}$-EG nanofluid with high nanoparticle concentration $\phi_{b}=10 \%$ ). It is important to notice that having nanofluids with high nanoparticle concentrations $\left(\phi_{b}>4 \%\right)$ is not recommended as the nanoparticle loadings increases the viscosity.

The comparison between the different nanoparticles viz. $\mathrm{Al}_{2} \mathrm{O}_{3}, \mathrm{TiO}_{2}, \mathrm{CuO}, \mathrm{SiO}_{2}$ and $\mathrm{ZnO}$ revealed that the $\mathrm{Al}_{2} \mathrm{O}_{3}$ nanoparticle with the three based fluids (water, ethylene glycol, and turbine oil) has a higher $\mathrm{Nu}$ due to the higher thermal capacity. The present results clearly showed that the addition of nanoparticles increases the $\mathrm{Nu}$ up to $16 \%$ as compared to the base fluid. For all the cases, the $\mathrm{Nu}$ enhancement becomes more pronounced due to nanoparticles. Two different boundary conditions were considered (constant heat flux and constant temperature), and thus two new convective heat transfer correlations were proposed for the straight tube covering a wide range of the process parameters $\left(25<\operatorname{Re}<1500,0<\phi_{b}<10,6<\operatorname{Pr}<500\right)$ under laminar flow condition. Also, a new $\mathrm{Nu}$ correlation for the straight microtube was proposed for the same range of process parameters to that of straight tube. The new correlations can be applicable to a wide range of applications that will allow this new field of study to move a step forward.

Author Contributions: C.I.R.-S.: conceptualization, methodology and supervision. R.R.-T.: investigation, formal analysis, validation and writing-original draft. J.S.: formal analysis, writing-review and editing. K.D.P.N.: supervision.

Funding: This research received no external funding. 
Acknowledgments: This research was supported by the Energy and Climate Change Research Group at Tecnologico de Monterrey.

Conflicts of Interest: The authors declare no conflicts of interest.

\section{Abbreviations}

$\begin{array}{ll}\mathrm{Al}_{2} \mathrm{O}_{3} & \text { Aluminum Oxide } \\ \mathrm{CuO} & \text { Copper Oxide } \\ \mathrm{HTC} & \text { Heat Transfer Coefficient } \\ \mathrm{SiO}_{2} & \text { Silicon Dioxide } \\ \mathrm{SPD} & \text { Single Phase Dispersion Model } \\ \mathrm{SPH} & \text { Single Phase Model } \\ \mathrm{TiO}_{2} & \text { Titanium Dioxide } \\ \mathrm{ZnO} & \text { Zinc Oxide } \\ \mathrm{Symbols} & \\ C_{p, n f} & \text { Specific Heat Capacity of Nanofluid }\left(\mathrm{J} \cdot \mathrm{kg}^{-1} \cdot \mathrm{K}^{-1}\right) \\ \mathrm{d}_{\mathrm{t}} & \text { Tube Inner Diameter }(\mathrm{mm}) \\ k_{e f f} & \text { Effective Thermal Conductivity of Nanofluid }\left(\mathrm{W} \cdot \mathrm{m}^{-1} \cdot \mathrm{K}^{-1}\right) \\ k_{d i s p} & \text { Dispersion Thermal Conductivity }\left(\mathrm{W} \cdot \mathrm{m}^{-1} \cdot \mathrm{K}^{-1}\right) \\ \mathrm{L} & \text { Length of the Tube }(\mathrm{m}) \\ \mu_{e f f} & \text { Effective Viscosity of Nanofluid }\left(\mathrm{kg} \cdot \mathrm{m}^{-1} \cdot \mathrm{s}^{-1}\right) \\ \mu_{d i s p} & \text { Dispersion Viscosity }\left(\mathrm{kg} \cdot \mathrm{m}^{-1} \cdot \mathrm{s}^{-1}\right) \\ \phi_{b} & \text { Volume Fraction of Nanoparticles }(\%) \\ \rho_{n f} & \text { Density of Nanofluid }\left(\mathrm{kg} \cdot \mathrm{m}^{-3}\right) \\ \mathrm{Nu} & \text { Nusselt Number } \\ \mathrm{T}_{\mathrm{m}} & \text { Fluid Mean Temperature }(\mathrm{K}) \\ \mathrm{U} & \text { Mean Velocity of Nanofluid }\left(\mathrm{m} \cdot \mathrm{s}^{-1}\right)\end{array}$

\section{References}

1. Pawar, S.S.; Nandi, S.; Salian, T.; Shenoy, G.; Shettty, S. A brief review on CFD work of helical coil and straight tube heat exchangers. Int. J. Phys. Appl. Sci. 2015, 2, 11.

2. Sunny, S.P.; Mhaske, S.D.; Parikh, Y.B. Numerical Simulation of a Tube in Tube Helical Coiled Heat Exchanger using CFD. Int. J. Appl. Eng. Res. 2014, 9, 18.

3. Gupta, M.; Arora, N.; Kumar, R.; Kumar, S.; Dilbaghi, N. A comprehensive review of experimental investigations of forced convective heat transfer characteristics for various nanofluids. Int. J. Mech. Mater. Eng. 2014, 9, 11. [CrossRef]

4. Akbaridoust, F.; Rakhsha, M.; Abbassi, A.; Saffar-Avval, M. Experimental and numerical investigation of nanofluid heat transfer in helically coiled tubes at constant wall temperature using dispersion model. Int. J. Heat Mass Transf. 2013, 58, 480-491. [CrossRef]

5. Shokouhi, A.; Keshazarz, A.; Ziabasharhagh, M.; Mojarrad, M.S.; Raveshi, M.R. Experimental Investigation of Nanofluid Convective Heat Transfer in the Entrance Region of a Circular Tube. In Proceedings of the ASME 3rd Micro/Nanoscale Heat \& Mass Transfer International Conference, MNHMT2012-75253. Atlanta, GA, USA, 3-6 March 2012.

6. Xuan, Y.; Li, Q. Heat transfer enhancement of nanofluids. Int. J. Heat Fluid Flow 2000, 21, 58-64. [CrossRef]

7. Nnanna, A.G. Experimental Model of Temperature-Driven Nanofluid. J. Heat Transf. 2006, 129, 697-704. [CrossRef]

8. Chandrasekar, M.; Suresh, S.; Bose, A.C. Experimental studies on heat transfer and friction factor characteristics of $\mathrm{Al}_{2} \mathrm{O}_{3}$ /water nanofluid in a circular pipe under laminar flow with wire coil inserts. Exp. Therm. Fluid Sci. 2010, 34, 122-130. [CrossRef]

9. Saeedinia, M.; Akhavan-Behabadi, M.A.; Nasr, M. Experimental study on heat transfer and pressure drop of nanofluid flow in a horizontal coiled wire inserted tube under constant heat flux. Exp. Therm. Fluid Sci. 2012, 36, 158-168. [CrossRef] 
10. Suresh, S.; Venkitaraj, K.P.; Selvakumar, P.; Chandrasekar, M. Effect of $\mathrm{Al}_{2} \mathrm{O}_{3}-\mathrm{Cu}$ / water hybrid nanofluid in heat transfer. Exp. Therm. Fluid Sci. 2012, 38, 54-60. [CrossRef]

11. Esmaeilzadeh, E.; Almohammadi, H.; Vatan, S.N.; Omrani, A.N. Experimental investigation of hydrodynamics and heat transfer characteristics of $\gamma-\mathrm{Al}_{2} \mathrm{O}_{3} /$ water under laminar flow inside a horizontal tube. Int. J. Therm. Sci. 2013, 63, 31-37. [CrossRef]

12. Gu, B.; Hou, B.; Lu, Z.; Wang, Z.; Chen, S. Thermal conductivity of nanofluids containing high aspect ratio fillers. Int. J. Heat Mass Transf. 2013, 64, 108-114. [CrossRef]

13. Rayatzadeh, H.R.; Saffar-Avval, M.; Mansourkiaei, M.; Abbassi, A. Effects of continuous sonication on laminar convective heat transfer inside a tube using water- $\mathrm{TiO}_{2}$ nanofluid. Exp. Therm. Fluid Sci. 2013, 48, 8-14. [CrossRef]

14. Lo, K.J.; Weng, H.C. Convective Heat Transfer of Magnetic Nanofluids in a Microtube. Smart Sci. J. 2015, 3, 56-64. [CrossRef]

15. Abu-Nada, E.; Masoud, E.; Oztpo, H.P.; Campo, A. Effect of nanofluid variable properties on natural convection in enclosures. Int. J. Therm. Sci. 2010, 4, 479-491. [CrossRef]

16. Colangelo, G.; Favale, E.; Milanese, M.; de Risi, A.; Laforgia, D. Cooling of electronic devices: Nanofluids contribution. Appl. Therm. Eng. 2017, 127, 421-435. [CrossRef]

17. Potenza, M.; Milanese, M.; Colangelo, G.; de Risi, A. Experimental investigation of transparent parabolic trough collector based on gas-phase nanofluid. Appl. Energy 2017, 203, 560-570. [CrossRef]

18. Roy, G.; Palm, S.J.; Nguyen, C.T. Heat transfer and fluid flow of nanofluids in laminar radial flow cooling systems. J. Therm. Sci. 2005, 14, 362-367. [CrossRef]

19. Bianco, V.; Manca, O.; Nardini, S.; Vafai, K. Heat Transfer Enhancement of Nanofluids; CRC Press: Boca Raton, FL, USA, 2017.

20. Wen, D.; Ding, Y. Experimental investigation into convective heat transfer of nanofluids at the entrance region under laminar flow conditions. Int. J. Heat Mass Transf. 2004, 47, 5181-5188. [CrossRef]

21. Maïga, S.E.B.; Palm, S.J.; Nguyen, C.T.; Roy, G.; Galanis, N. Heat transfer enhancement by using nanofluids in forced convection flows. Int. J. Heat Fluid Flow 2005, 26, 530-546. [CrossRef]

22. Heris, S.Z.; Etemad, S.G.; Esfahany, M.N. Experimental investigation of oxide nanofluids laminar flow convective heat transfer. Int. Commun. Heat Mass Transf. 2006, 33, 529-535. [CrossRef]

23. Anoop, K.B.; Sundararajan, T.; Das, S.K. Effect of particle size on the convective heat transfer in nanofluid in the developing region. Int. J. Heat Mass Transf. 2009, 52, 2189-2195. [CrossRef]

24. Hwang, K.S.; Jang, S.P.; Choi, S. Flow \& convective heat transfer characteristics of water-based $\mathrm{Al}_{2} \mathrm{O}_{3}$ nanofluids in fully developed laminar flow regime. Int. J. Heat Mass Transf. 2009, 52, 193-199.

25. Davarnejad, R.; Barati, S.; Kooshki, M. CFD simulation of the effect of particle size on the nanofluids convective heat transfer in the developed region in a circular tube. SpringerPlus 2013, 2, 192. [CrossRef] [PubMed]

26. Kim, D.; Kwon, Y.; Cho, Y.; Moon, S. Convective heat transfer characteristics of nanofluids under laminar and turbulent flow conditions. Curr. Appl. Phys. 2009, 9, 119-123. [CrossRef]

27. Rea, U.L.; McKrell, T.; Hu, L. Laminar convective heat transfer and viscous pressure loss of alumina-water and zirconia-water nanofluids. Int. J. Heat Mass Transf. 2009, 52, 2042-2048. [CrossRef]

28. Purohit, N.; Purohit, V.A.; Purohit, K. Assessment of nanofluids for laminar convective heat transfer: A numerical study. Eng. Sci. Technol. Int. J. 2016, 19, 574-586. [CrossRef]

29. Haghighi, E.B.; Saleemi, M.; Nikkam, N.; Khodabandeh, R.; Toprak, M.S.; Muhammed, M.; Palm, B. Accurate basis of comparison for convective heat transfer in nanofluids. Int. Commun. Heat Mass Transf. 2014, 52, 1-7. [CrossRef]

30. Salman, B.H.; Mohammed, H.A.; Kherbeet, A.Sh. Heat Transfer Enhancement of nanofluids flow in microtube with constant heat flux. Int. Commun. Heat Mass Transf. 2012, 39, 1195-1204. [CrossRef]

31. Liu, Y.; Hu, H. Numerical investigation of nanofluid convection performance in the fully developed flow regime of the pipe with constant wall temperature. In IOP Conference Series: Earth and Environmental Science; IOP Publishing Ltd.: Bristol, UK, 2017; Volume 59, Conference 1.

32. Göktepe, S.; Atalik, K.; Ertürk, H. Comparison of single and two-phase models for nanofluid convection at the entrance of a uniformly heated tube. Int. J. Therm. Sci. 2014, 80, 83-92. [CrossRef]

33. Wang, X.Q.; Mujumdar, A.S. A review on nanofluids-Part I: Theoretical and numerical investigations. Braz. J. Chem. Eng. 2008, 25, 613-630. [CrossRef] 
34. Pak, B.C.; Cho, Y.I. Hydrodynamic and heat transfer study of dispersed fluids with submicron metallic oxide particles. Exp. Heat Transf. 1999, 11, 151-170. [CrossRef]

35. Ho, C.J.; Liu, W.K.; Chang, Y.S.; Lin, C.C. Natural convection of microparticle suspensions in thin enclosures. Int. J. Heat Mass Transf. 2008, 51, 1332-1341.

36. Das, S.K.; Putra, N.; Thiesen, P.; Roeztzel, W. Temperature dependence of thermal conductivity enhancement for nanofluids. J. Heat Transf. 2003, 125, 567-574. [CrossRef]

37. Khanafer, K.; Vafai, K. A critical synthesis of thermophysical characteristics of nanofluids. Int. J. Heat Mass Transf. 2011, 54, 4410-4428. [CrossRef]

38. Brinkman, H.C. The viscosity of concentrated suspensions and solutions. J. Chem. Phys. 1952, $20,571$. [CrossRef]

39. Lundgren, T. Slow flow through stationary random beds and suspensions of spheres. J. Fluid Mech. 1972, 51, 273-299. [CrossRef]

40. Batchelor, G. The effect of Brownian motion on the bulk stress in a suspension of spherical particles. J. Fluid Mech. 1977, 83, 97-117. [CrossRef]

41. Hamilton, R.L.; Crosser, O.K. Thermal Conductivity of heterogeneous two-component systems. Ind. Eng. Chem. Fundam. 1962, 1, 182-191. [CrossRef]

42. Maxwell, J.C.A. Treatise on Electricity and Magnetism, 2nd ed.; Clarendon Press: Oxford, UK, 1881.

43. Buongiorno, J.; Venerus, D.C.; McKrell, T.; Townsend, J. A Benchmark Study on the Thermal Conductivity of Nanofluids. J. Appl. Phys. 2009, 106, 094312. [CrossRef]

44. Mansour, R.B.; Galanis, N.; Nguyen, C.T. Effect of uncertainties in physical properties on forced convection heat transfer with nanofluids. Appl. Therm. Eng. 2007, 27, 240-249. [CrossRef]

45. Sarkar, J. A critical review on convective heat transfer correlations of nanofluids. Renew. Sustain. Energy Rev. 2011, 15, 3271-3277. [CrossRef]

46. Tertsinidou, G.J.; Tsolakidou, C.M.; Pantzali, M.; Assael, M.J. New Measurements of the Apparent Thermal Conductivity of Nanofluids and Investigation of Their Heat Transfer Capabilities. J. Chem. Eng. Data 2017, 62, 491-507. [CrossRef]

47. Heris, S.Z.; Farzin, F.; Sardarabadi, H. Experimental Comparison among Thermal Characteristics of Three Metal Oxide Nanoparticles/Turbine Oil-based Nanofluids Under Laminar Flow Regime. Int. J. Thermophys. 2015, 36, 760-782. [CrossRef]

48. Singh, J.; Choudhary, N.; Nigam, K.D.P. The Thermal and Transport Characteristics of Nanofluids in a Novel Three-Dimensional Device. Can. J. Chem. Eng. 2014, 94, 2185-2201.

49. Heris, S.Z.; Etemad, S.G.; Esfahany, M.N. Experimental investigation of convective heat transfer for $\mathrm{Al}_{2} \mathrm{O}_{3}$ /water nanofluid in circular tube. Int. J. Heat Fluid Flow 2007, 28, 203-210. [CrossRef]

50. Ting, H.H.; Hou, S.S. Numerical Study of Laminar Flow Forced Convection of Water- $\mathrm{Al}_{2} \mathrm{O}_{3}$ Nanofluids under Wall Temperature Condition. Math. Probl. Eng. 2015, 2015, 180841. [CrossRef]

51. Shah, R.K. Thermal entry length solutions for the circular tube and parallel plates. In Proceedings of the 3rd National Heat and Mass Transfer Conference, Bombay, India, 11-13 December 1975; Indian Institute of Technology: Bombay, India, 1975; Volume I, pp. 11-75.

52. Haghighi, E.B.; Anwar, Z.; Lumbreras, I.; Mirmohammadi, S.A.; Behi, M.; Khodabandeh, R.; Palm, B. Screening Single Phase Laminar Convective Heat Transfer of Nanofluids in a Micro-tube. J. Phys. Conf. Ser. 2012, 395, 012036. [CrossRef]

53. Salman, B.H.; Mohammed, H.A.; Kherbeet, A.S. The effect of base fluid type in nanofluids for heat transfer enhancement in microtubes. In Proceedings of the International Conference on Energy and Thermal Science, Johor, Malaysia, 1 October 2014; University Technology Malaysia: Johor, Malaysia, 2014.

(C) 2018 by the authors. Licensee MDPI, Basel, Switzerland. This article is an open access article distributed under the terms and conditions of the Creative Commons Attribution (CC BY) license (http://creativecommons.org/licenses/by/4.0/). 